\title{
ОСОБЛИВОСТІ УПРАВЛІННЯ ПРОМИСЛОВИМИ ТРАНСФОРМАЦІЯМИ В УМОВАХ ЦИФРОВІЗАЦІї
}

\section{PECULIARITIES OF INDUSTRIAL TRANSFORMATION MANAGEMENT IN THE CONDITIONS OF DIGITALIZATION}

\author{
Квасній Любов Григорівна \\ кандидат економічних наук, доцент, \\ Дрогобицький державний педагогічний університет \\ імені Івана Франка \\ ORCID: https://orcid.org/0000-0001-5248-544X \\ Солтисік Оксана Орестівна \\ кандидат економічних наук, доцент, \\ Дрогобицький державний педагогічний університет \\ імені Івана Франка \\ ORCID: https://orcid.org/0000-0003-3054-0158 \\ Ковалько Маркіян Степанович \\ магістр, \\ Дрогобицький державний педагогічний університет \\ імені Івана Франка \\ ORCID: https://orcid.org/0000-0001-1996-2020
}

\author{
Kvasnii Liybov, Soltysik Oksana, Kovalко Markian \\ Drohobych State Pedagogical Ivan Franko University
}

\begin{abstract}
Стаття присвячена актуальним питанням управління комунікаціями в умовах цифровізації. В статті акцентовано увагу на тому, що четверта промислова революція уже не є просто концепцією, оскільки стандарти «Індустрії 4.0» вже активно впроваджуються в європейських країнах. Обґрунтовано, що посилення поглибленого обміну та співпраці у сфрері інновацій та застосування індустрії великих даних $€$ важливим напрямком для поглиблення скоординованого розвитку в Україні. Доведено, що промисловий Інтернет $\epsilon$ важливим проривом у сприянні цифровій трансформації підприємств. У цьому зв'язку прискорилася інтеграція промислового Інтернету з реальною економікою, а отже доцільне впровадження відповідних програм. Наголошено, що такі технології, як великі дані та штучний інтелект, слід поглибити 3 інтеграцією реальної економіки, і продовжувати сприяти цифровізації промисловості, зміцнювати інтегровані галузі та змінювати виробничі методи, моделі обслуговування та організаційні фрорми, що підвищить стійкість до розвитку реальної економіки.
\end{abstract}

Ключові слова: цифровізація, промислові трансформації, економічний розвиток, Індустрія 4.0.

Статья посвящена актуальным вопросам управления коммуникациями в условиях цифровизации. В статье акцентировано внимание на том, что четвертая промышленная революция уже не просто концепция, поскольку стандарты «Индустрии 4.0» уже активно внедряются в европейских странах. Обосновано, что усиление углубленного обмена и сотрудничества в сфрере инноваций и применение индустрии крупных данных является важным направлением углубления скоординированного развития в Украине. Доказано, что промышленный Интернет является важным прорывом в содействии цифровой трансформации предприятий. В этой связи ускорилась интеграция промышленного Интернета с реальной экономикой, а следовательно, целесообразно внедрение соответствующих программ. Отмечено, что такие технологии, как большие данные и искусственный интеллект, следует углубить с интеграцией реальной экономики и продолжать способствовать циорровизации промышленности, укреплять интегрированные отрасли и изменять производственные методы, модели обслуживания и организационные формы, что повысит устойчивость к развитию реальной экономики.

Ключевые слова: цифровизация, промышленные трансформации, экономическое развитие, промышленность 4.0 . 
The article is devoted to topical issues of communications management in the context of digitalization. The aim of the article is to substantiate the main theoretical approaches, features and problems of communication management in the development of "Industry 4.0" in Ukraine. The article emphasizes that the fourth industrial revolution is no longer just a concept, as Industry 4.0 standards are already being actively implemented in European countries. It is substantiated that strengthening in-depth exchange and cooperation in the field of innovation and application of the big data industry is an important direction for deepening coordinated development in Ukraine. It has been proven that the industrial Internet is an important breakthrough in promoting the digital transformation of enterprises. In this regard, the integration of the industrial Internet with the real economy has accelerated, and therefore the implementation of appropriate programs is appropriate. It is emphasized that technologies such as big data and artificial intelligence should be deepened with the integration of the real economy, and continue to promote digitalization, strengthen integrated industries and change production methods, service models and organizational forms, which will increase resilience to the real economy. It has been proven that the development of the digital economy contributes to the strengthening of internal communication and social integration. Based on the analysis of scientific research, it was found that strengthening in-depth exchange and cooperation in the field of innovation and the application of the big data industry is an important direction for deepening coordinated development. The benefits of the big data industry complement each other. Promoting the digital transformation of government, building smart cities and improving the blockchain of products will contribute to national security and economic development. It is established that in the context of normalization of prevention and control of the coronavirus epidemic, the benefits of the digital economy in European countries are growing, namely: various online services such as e-government, distance learning, online education and online health services have shown rapid growth and great potential for development. The article argues the need to form a new logic of industrial development and use it to manage industrial development. Managers need to keep in mind that the digital age should not replicate the industrial logic of the industrial age, as it will not be able to work effectively in the current environment. In order to more rapidly implement the latest technologies of Industry-4.0, Ukraine needs to analyze and adopt the experience of other countries.

Keywords: digitalization, communications, economic development, Industry 4.0.

Постановка проблеми. Соціально-економічний розвиток сучасної епохи характеризується поступовим витісненням на другий план матеріальних ресурсів та зростанням ролі таких ресурсів як інсрормація та знання [1, с. 103].

Як нова економічна фрорма, що веде майбутнє, цифррова економіка $є$ не лише новою змінною для покращення економічної якості та ефективності діяльності господарюючих суб'єктів ринку, але й новим напрямом економічної трансорормації та розвитку. Протягом останніх років в усьому цивілізованому світі надається велике значення розвитку цисррової економіки, здійснюються низка важливих заходів, активних дій зі сторони різних відомств та міністерств.

Реалізація інфрормаційно-комунікаційних можливостей та переваг новітніх технологій, необхідність набуття лідируючих позицій і зміцнення конкурентоспроможності секторів економіки у глобалізованому цифровому світі вимагають від уряду зваженої політики щодо цисрровізації, лібералізації регулювання, адаптації нормативної бази, стимулювання інвестицій для просування цифрової економіки, враховуючи власні традиції і спираючись на наукове підґрунтя теорій і концепцій економічного розвитку [2, с. 62].

Усі ми є свідками того, що четверта промислова революція уже не $є$ просто концепцією, оскільки стандарти «Індустрії 4.0» вже активно впроваджуються в європейських країнах.
Аналіз останніх досліджень і публікацій. Проблеми, вплив і перспективи впровадження Індустрії 4.0 та цифррової економіки досліджують як українські так і зарубіжні вчені: О. Амоша [2, с. 58]; І. Булєєв [3, с. 116-132] обґрунтовують парадигму активізації інвестиційної діяльності підприємств в умовах системної кризи і падаючих ринків, метою якої $€$ розвинена промисловість з Індустрією 4.0.

Перспективи, напрями і механізми смарт-промисловості та цифрової економіки знайшли відображення в дослідженнях В. Вишневського, О. Вієцької, О. Гаркушенка, С. Князєва, О. Ляха, В. Чекіної, Д. Череватського [4, с. 192].

Виділення невирішених раніше частин загальної проблеми. На фроні масової цифрровізації в глобальному просторі відставання України все більше поглиблюється. Невирішеним в Україні $€$ питання широкого впровадження принципів «Індустрії 4.0» на вітчизняних підприємствах та цисрровізація промисловості загалом. Незважаючи на велику кількість публікацій щодо стану та перспектив впровадження «Індустрії 4.0» в Україні, вважаємо недостатньо висвітленими питання особливостей впровадження та розвитку технологій «Індустрії 4.0» в енергетиці, рітейлі, АПК, фрінансах, будівництві, фрармацевтиці, транспорті та логістиці, машинобудуванні а також особливостей управління комунікаціями. 
Формулювання цілей статті (постановка завдання). Метою статті $€$ обґрунтування основних теоретичних підходів, особливостей та проблем щодо управління комунікаціями в умовах розвитку «Індустрії 4.0» в Україні.

Виклад основного матеріалу дослідження. Синергетичний ефрект від використання технологій та інструментів комунікативного менеджменту полягає в досягненні ефрективного кінцевого результату функціонування економічної системи. Це може служити ще одним аргументом на користь інтегрованої комунікації (integrated communication) як основи комунікативного менеджменту. Крім того, зв'язки з громадськістю, засобами масової інфрормації та інші технології і інструменти комунікативного менеджменту пропонується розглядати як частину системи комунікації.

Загалом інформаційно-комунікативну сореру суспільства можна розглядати в контексті дослідження типології комунікативного менеджменту в таких аспектах:

1. ієрархічно-територіального рівня і простору управління;

2. базових сорер суспільства (економічної, державно-правової, духовної);

3. галузево-фрункціональних видів менеджменту;

4. ієрархічно-регулятивного рівня управління;

5. часового простору управління.

Проведені дослідження та аналіз дали змогу встановити, що в епоху після епідемії постало актуальним використання інфрормаційних технологій для прискорення цисрової трансформації. Індустрія цисррового розширення прав і можливостей привертає увагу та відкриває можливості не лише для внутрішнього, а й для глобального розвитку.

Все більше європейських країн стають справжніми державами з цифровою економікою в майбутньому, лідерами у глобальному цифрровому розвитку. В контексті нормалізації профрілактики та боротьби з епідемією, додатково підкреслюються переваги цисррової економіки в європейських країнах, а також різноманітні онлайн-сервіси, такі як електронний уряд, дистанційний офріс, онлайн-освіта та онлайнмедичні послуги продемонстрували стрімке зростання і великий потенціал розвитку.

Розвиток цифрової економіки потребує міцного фрундаменту. «Нова інфрраструктура $\epsilon$ не лише важливою частиною розвитку цифррової економіки, але й основою для їі розвитку. Дивлячись на світ, велика кількість динамічних цифррових підприємств, таких як електронна комерція, фрінанси, логістика, хмарні обчислення, розваги та інші сфери, процвітають у цифровій економіці, постійно оновлюючи свою економічну життєздатність. Отже оцифровка глобального промислового ланцюга значно прискорилася, відкриваючи нові можливості.

Світова практика показує, що $5 \mathrm{G} є$ ключовою новою інсрраструктурою, яка підтримує цифррову, мережеву та інтелектуальну трансформацію вертикальних індустрій. Міністерство $з$ питань стратегічних галузей промисловості України наголосило на технічних характеристиках та сценаріях застосування 5G. Тому необхідно зробити його важливим двигуном для розвитку цисррової економіки.

Згідно з розрахунками науковців з інфрормаційних і комунікаційних технологій, з 2020 по 2025 рік 5G сприятиме зростанню цифрової економіки; очікується, що технологія 5G сприятиме розвитку інших галузей.

Наразі 5G вступає в критичний період комерційного використання, і прискорення розвитку 5G є одним із важливих заходів для координації запобігання епідемії та контролю за ними з метою економічного та соціального розвитку.

Науковці зазначають, що основні Інтернет-ресурси $€$ важливим наріжним каменем розвитку цифрової економіки багатьох країн. У довгостроковій перспективі необхідно посилити прорив базових технологій у сорері базових інтернет-ресурсів 3 трьох аспектів мікро, мезо та макро. Необхідно прорватися через основні технології квантових мереж і супутників Інтернет якомога швидше та прискорити просування політики екології, технологічної екології та промислової екології основних Інтернет-ресурсів .

Важливим завданням $€$ також: підвищити рівень інтеграції. Наразі цифрова економіка глибоко інтегрована в усі сорери економіки та суспільства, стає важливою рушійною силою для сприяння якісним, ефективним та потужним змінам економічного розвитку.

Сьогодні все більше і більше заходів реалізовуються. здійснюється через Інтернет. Цисррову трансформацію неможливо зупинити. Вона також спричиняє зміни у методах виробництва, способі життя та управлінні.

Налаштування та оптимізація значно підвищить ефективність і стійкість ланцюга поставок; по-друге, оцисрровка глобального промислового ланцюга сприятиме інноваційним технологіям та бізнес-моделям, створить більше цінності для суспільства та принесе більше зручностей у життя людей. 
Сьогодні багато країн розглядають цифррову економіку як важливий двигун майбутнього економічного зростання. Минулого року річний онлайн-продаж в Сербії майже подвоївся порівняно з минулим роком, а безготівкові розрахунки в Польщі вперше перевищили готівкові. Країни Центральної та Східної Європи посилили цисррову трансорормацію державних справ та електронне оподаткування під час запобігання епідемії та контрольний період.

Зарубіжний досвід показує, що завдяки глибокій участі китайських компаній послуги електронної комерції та цифррових платежів у Латинській Америці швидко розвиваються. В Аргентині електронні платежі зросли на $29 \%$ у 2020 році, а частка платежів за кодом сканування мобільного телефону зросла до $54,3 \%$. Вважаємо, що розвиток цифрової економіки сприяє зміцненню внутрішнього зв'язку та соціальної інтеграції. Сприяння цифровій трансорормації уряду, побудова розумних міст та покращення блокчейну продуктів сприятимуть національній безпеці та економічному розвитку.

Циррова економіка продемонструвала сильну стійкість до потрясінь і стійкість до розвитку, що сприяло економічному зростанню багатьох країн минулого року всупереч тенденції.

Цифррові технології є важливою підтримкою та гарантією перемоги в боротьбі з бідністю. Виробники з бідних районів чи країн активно беруть участь у національному процесі цифровізації, використовують платсоорми електронної комерції для продажу продукції та значно збільшують свої доходи. Цифрова економіка не тільки глибоко змінила виробництво та спосіб життя, але й відкрила нові горизонти для світу». Співпраця в передових сорерах, таких як цифрова економіка, штучний інтелект, нанотехнології та квантові комп'ютери відображає точно погляди щодо тенденцій розвитку світової економіки.

Очікується, що світовий ринок промислової Інтернет-платорорми буде зростати із середньорічними темпами зростання 33,4\% до 2035 року. Важливим $€$ прискорення розвитку промислового Інтернету. Очікується, що інтелектуальний промисловий Інтернет забезпечить глобальне економічне зростання на 30 трильйонів доларів США.

Промисловий Інтернет є важливим проривом у сприянні цифровій трансорормації підприємств. Зараз надається великого значення розвитку промислового Інтернету, і уряди всіх рівнів запровадили політику та заходи для прискорення розвитку промислового Інтернету. Під керівництвом політики всі сторони галузі активно співпрацюють, щоб досліджувати технологічні інновації та екологічну конструкцію промислового Інтернету. Інтеграція промислового Інтернету з реальною економікою прискорилася, і повинні впроваджуватися відповідні програми. Такі технології, як великі дані та штучний інтелект, слід поглибити 3 інтеграцією реальної економіки, і продовжувати сприяти цисрровізації промисловості, зміцнювати інтегровані галузі та змінювати виробничі методи, моделі обслуговування та організаційні форми, що підвищить стійкість до розвитку реальної економіки.

Перш за все, слід оптимізувати товарні запаси та заохочувати підприємства до підвищення якості та есрективності та зниження витрат. Необхідно активно заохочувати інновації та розвиток промислового Інтернету, широко впроваджувати цифррові, мережеві та інтелектуальні перетворення підприємств, особливо виробничих підприємств, щоб допомогти підприємствам зменшити витрати на робочу силу та експлуатацію, оптимізувати розподіл ресурсів та значно підвищити ефективність роботи у всіх аспектах.

Завдяки перехресному обладнанню, міжсистемному, міжзаводському, міжрегіональному всеосяжному взаємозв'язку реалізуються оптимізація багатьох ресурсів, багатовимірні інновації та співпраця виробництва та роботи підприємства, сприяючи, таким чином, розумному оновленню системи виробничих послуг та розширення ланцюга створення вартості та стимулювання високоякісних технологій, високоякісні продукти та високоякісне обладнання призведуть до реструктуризації моделі корпоративного розвитку для гнучкого виробництва, швидкого реагування та екологічного фрункціонування та породять нові бізнес-орормати, такі як персоналізоване налаштування, мережева співпраця та сервісно-орієнтоване розширення.

У цьому зв'язку вважаємо доцільним: прискорити темпи інновацій та розвитку промислового Інтернету, усвідомити швидке зближення інноваційних ресурсів між галузями, регіонами, часом і простором, сприяти ефективному спільному використанню людських ресурсів і глибокій інтеграції передового виробництва та сучасних індустрій послуг.

Висновки. На думку багатьох науковцівекономістів, розвиток цифрової економіки змінює структуру промисловості, а також реконструює промислову логіку. Наприклад, від 
конкурентних переваг до «створення спільної роботи», від економії масштабу до економії обсягу, від організаційного управління до управління на основі платформ, корпоративні організації переходять від ієрархічної до мережевої структури, від централізації до трансформації на основі платформи, а також від робити проекти, щоб займатися екологією.

Загалом, визначено, що більшість вітчизняних підприємств не прагнуть до використання технологій «Індустрії 4.0» у власних виробничих процесах та схильні до використання традиційних методів виробництва.

Вважаємо, що в майбутньому цифрова транссормація, керована промисловим Інтернетом, прискориться, а соціалізована парадигма виробництва С2М стане важливою ознакою фрункціонування промислової системи. Міжгалузева інтеграція та інновації породили нові моделі, нові фоормати бізнесу та ресормовані системи виробництва та обслуговування. У той же час інтеграція нових технологій, таких як 5G та Al, спричинить глибокі зміни в системі підтримки промисловості.

Тому вважаємо, що зіткнувшись із цисрровою епохою, необхідно сорормувати нову логіку промислового розвитку та використовувати її для управління промисловим розвитком. Управлінцям необхідно врахувати, що цифрова ера не повинна повторювати індустріальну логіку індустріальної ери,оскільки вона не зможе ефективно працювати в теперішніх умовах. Для більш стрімкого впровадження новітніх технологій «нндустрії-4.0» Україні необхідно аналізувати та переймати досвід інших країн.

\section{СПИСОК ВИКОРИСТАНИХ ДЖЕРЕЛ:}

1. Пантєлєєва Н.М., Колодій С.Ю., Ребрик М.А. Цифрова економіка як ключовий тренд розвитку постіндустріального суспільства : монограсрія. Київ : ДВНЗ «Університет банківської справи», 2019. 299 с.

2. Амоша О. Щоб змінилася погода, потрібний не поривчастий вітер, а загальна зміна клімату. Дзеркало тижня. (28 грудня - 13 січня), 2018. № 49-50.

3. Брюховецька Н., Черних О. Індустрія 4.0 та цисрровізація економіки: можливості використання зарубіжного досвіду на промислових підприємствах України. Економіка промисловості. 2020. № 2(90). С. 116-132.

4. Вишневський В., Вієцька О., Гаркушенко О. Смарт-промисловість в епоху цифрової економіки: перспективи, напрями і механізми розвитку. Київ : Інститут економіки промисловості НАН України, 2018. 192 с.

5. Гаряга Л.О. Розвиток фрінансового ринку в умовах цифровізації економіки. Бізнес Інфоорм. 2018. № 11. С. 388-393.

\section{REFERENCES:}

1. Panteleeva N.M., Kolodii S.Yu., Rebryk M.A. (2019) Tsyfrova ekonomika yak klyuchova tendentsiya rozvytku postindustrial'noho suspil'stva [Digital economy as a key trend in the development of post-industrial society]: monohrafiya [a monograph]. Kyiv: DVNZ "Universytet bankivs'koyi spravy", 229 p. (in Ukrainian)

2. Amosha O.I. (2018) Schob zminilasia pogoda, potribnuj ne porivtcshastuj viter, a zagalna zmina klimaty [To change the weather, you do not need gusty winds, but general climate change]. Dzerkalo tujniya. (Gruden 28 Sitchen 13), no. 49-50.

3. Bryukhovetska N., Chernykh O. (2020) Industrija 4,0 ta tsyfrovisatsija ekonomiky: mojluvosty vukoristannia zarubijnogo doswidu na promuslovikx pidpruemstvacsh Ukraine [Industry 4.0 and digitalization of the economy: opportunities for using foreign experience at industrial enterprises of Ukraine]. Economica promuslovosty, no. 2(90), $116-132$.

4. Vishnevsky V., Vietskaya O., Garkushenko O. (2018) Smart-promyslovist w epokchu tsyfrovoji ekonomiku: perspektiwy, naprjiamu I mekchanizmu rozwitku [Smart industry in the digital economy: prospects, directions and mechanisms of development]. Kyiv: Institut economiku promuslowosty NAN Ukraine, $192 \mathrm{p}$.

5. Gariyaga L.O. (2018) Rozwytok finansowogo runku w umovach tsyfrovisatsiji ekonomiky [Development of the financial market in the conditions of digitalization of economy]. Biznes Inform, no. 11, pp. 388-393. 